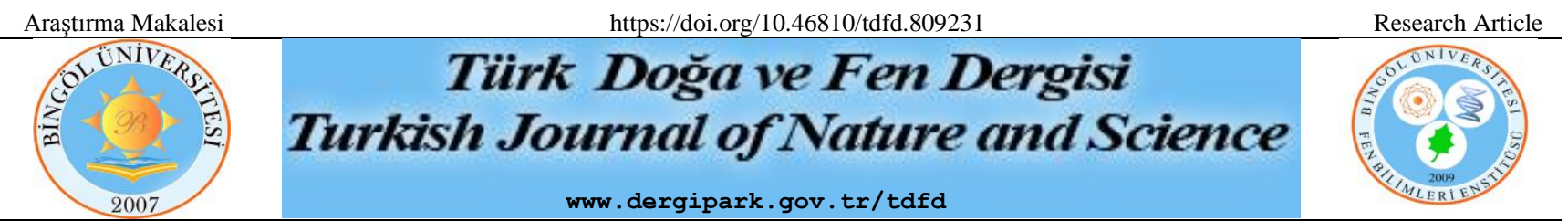

\title{
Rutinin Ratlarda Kolistin Kaynaklı Testis Hasarında Oksidatif DNA Hasarı, NF-кB Aracılı Enflamasyon ve Apoptoz Üzerindeki Koruyucu Etkileri
}

\author{
Selim ÇOMAKLI ${ }^{*}$, Mustafa İLERİTÜRK² ${ }^{2}$ Esra MANAVOĞLU KİRMAN ${ }^{1}$ \\ ${ }^{1}$ Atatürk Üniversitesi, Veteriner Fakültesi, Patoloji Bölümü, Erzurum, Türkiye \\ ${ }^{2}$ Atatürk Üniversitesi, Veteriner Fakültesi, Biyokimya Bölümü, Erzurum, Türkiye \\ Selim ÇOMAKLI ORCID No: 0000-0002-8744-7686 \\ Mustafa İLERİTÜRK ORCID No: 0000-0002-4581-4492 \\ Esra MANAVOĞLU KİRMAN ORCID No: 0000-0003-3877-7686
}

*Sorumlu yazar: selim.comakli@atauni.edu.tr

(Alınış: 12.10.2020, Kabul: 18.12.2020, Online Yayınlanma: 30.12.2020)

Anahtar
Kelimeler
Apoptoz,
Enflamasyon,
Kolistin,
Oksidatif
stres,
8-OHdG,
Testis

\section{Anahtar}

Apoptor

Enflamasyon,

Kolistin,

stres,

Testis

\begin{abstract}
Öz: Kolistin, gram-negatif bakterilerin neden olduğu enfeksiyonlarda tedavi amaciyla son seçenek olarak kullanılmaktadır. Literatürde kolistinin neden olduğu testis toksisitesi bildirilmiş olmasına rağmen mekanizmasına ilişkin çok az veri bulunmaktadır. Yapılan bu çalışmanın amacı kolistin uygulamasının neden olduğu testis toksisitesinde rutinin (Rut) koruyucu etkilerinin araştırılmasıdır. Bu amaç için 5 adet deneysel grup oluşturuldu; Kontrol, Rut (100 mg kg gün $\left.{ }^{-1}\right)$, Kolistin (15 mg kg gün $\left.^{-1}\right)$, Kolistin + Rut (50 mg kg gün $\left.{ }^{-1}\right)$, Kolistin + Rut (100 mg kg gün $\left.{ }^{-1}\right)$. Uygulama sonrasında ratların testis dokularında malondialdehit (MDA) ve redükte glutatyon (GSH) seviyeleri tespit edildi. Aynı zamanda testis dokularının histopatolojik incelemesi yapıldı ve 8-hidroksi-2'deoksiguanozin (8-OHdG), nükleer faktörü kappa $\mathrm{B}(\mathrm{NF}-\kappa \mathrm{B})$ ve kaspaz 3 aktiviteleri immunohistokimya ile belirlendi. Sonuçlara bakıldığında kolistin uygulamasının rat testis dokularında MDA düzeyini arttırdığı, GSH düzeyini ise azalttığı tespit edilmiştir. Farklı dozlarda Rut uygulaması sonrası ise MDA düzeyinde azalma, GSH düzeyinde ise artı̧̧ gözlendi. Kolistinin testis dokularında neden olduğu hasar sonucu $8-\mathrm{OHdG}, \mathrm{NF}-\kappa \mathrm{B}$ ve kaspaz 3 immunpozitifliklerinin arttığı, özellikle Rut (100 mg kg gün ${ }^{-1}$ ) uygulamasından sonra bu proteinlerin aktivite düzeylerinin azaldığı belirlendi. Sonuç olarak kolistinin rat testislerinde oksidatif hasar, enflamasyon, DNA hasarı ve apoptoza neden olduğu, Rut uygulamasının kolistin kaynaklı testis hasarında koruyucu etki gösterdiği belirlendi.
\end{abstract}

\section{Protective Effects of Rutin on Oxidative DNA Damage, NF-кB-Mediated Inflammation, and Apoptosis in Colistin-Induced Testicular Damage of Rats}

Keywords
Apoptosis,
Colistin,
Inflammation,
Oxidative
stress,
8-OHdG,
Testicle

Keywords

Apoptosis,

Colistin,

Oxidative

$8-\mathrm{OHdG}$

Testicle

\begin{abstract}
Colistin is used as the last-line therapy for treatment of infections caused by gramnegative bacteria. Although testicular toxicity caused by colistin has been reported in the literature, there are very few data regarding its mechanism. The aim of this study was to investigate the protective effects of rutin (Rut) in testicular toxicity caused by colistin treatment. For this purpose, five experimental groups were composed; Control, Rut (100 mg kg day $\left.{ }^{-1}\right)$, Colistin(15 mg kg day $\left.{ }^{1}\right)$, Colistin plus Rut $\left(50 \mathrm{mg} \mathrm{kg} \mathrm{day}^{-1}\right)$, Colistin + Rut (100 $\left.\mathrm{mg} \mathrm{kg} \mathrm{day}^{-1}\right)$. After the treatment, malondialdehyde (MDA) and glutathione (GSH) levels were determined in testicular tissues of rats. Furthermore, histopathological examination of testicular tissues, 8-hydroxy-2' deoxyguanosine (8-OHdG), nuclear factor-kappa $\mathrm{B}(\mathrm{NF}-\kappa \mathrm{B})$ and caspase 3 activities were determined by immunohistochemistry. It was found that colistin treatment increased the MDA level in rat testicular tissues and decreased the GSH level. However, after Rut treatment, a decrease in MDA level and an increase in GSH level were observed. As a result of the toxicity caused by colistin in testicular tissues, it was determined that $8-\mathrm{OHdG}, \mathrm{NF}-\mathrm{\kappa B}$ and caspase 3 activities increased, and the activity levels of these protein levels decreased after Rut 100 administration. As a conclusion, it was detected that while colistin caused oxidative damage, inflammation, DNA damage, and apoptosis in rat testicular tissues, Rut treatment had a protective effect in colistininduced testicular damage.
\end{abstract}




\section{GÍRİ̧}

Katyonik bir polipeptit antibiyotiği olan kolistin (polimiksin E), Bacillus polymyxa alt türü olan Bacillus colistinus Koyama tarafindan sentezlenir ve Pseudomonas aeruginosa, Acinetobacter baumannii ve Klebsiella pneumoniae gibi çoklu ilaca dirençli gramnegatif bakteriler üzerinde bakterisidal ve antiendotoksin etkiler gösterir [1-3]. Bu özelliklerine rağmen, kolistinin neden olduğu böbrek hasarı zararlı bir klinik komplikasyondur. İlaca bağlı nefrotoksisite, kolistin tedavisi için doz sınırlayıcı bir faktör görevi görür ve hastalarda ilaç etkinliğini azaltır [4]. Klinik kullanımlarını sınırlayan önemli yan etkilerden biri ise esas olarak hayvanlarda ve hastalarda parestezi, ataksi ve apati şeklinde ortaya çıkan nörotoksisitedir [5]. Kolistin, oldukça zararlı hidroksil radikallerinin $(\bullet \mathrm{OH})$ üretimini uyararak Gram-negatif bakteri hücresi ölümüne yol açar. Ancak, $\bullet \mathrm{OH}$ oluşumunun altında yatan mekanizma henüz çok net değildir. $\mathrm{H} 2 \mathrm{O} 2$ ve $\mathrm{OH}$ dahil olmak üzere biyolojik oksidatif türleri olan reaktif oksijen türlerinin (ROS) konsantrasyonu kontrol edilemeyen seviyeye ulaştığında, DNA, lipidler ve proteinlerde oksidatif hasara yol açacaktır [6]. Oksidatif hasardaki artış, sperm kalitesinde bir azalmaya yol açar ve testis dokusunda apoptoz ve otofajinin indüksiyonu gibi üreme parametreleri üzerinde zararlı etkiler meydana getirir [7].

Flavonoidler, ikincil bitki metabolitleri olan ve tüm bitki metabolitlerinde doğal olarak bulunan fenolik bileşiklerdir [8]. Rutin (3,3',4', 5,7-pentahydroxyflavone3 - ramnoglucoside, Rut) karabuğday, domates yaprağı, 1spanak, soğan, elma ve çayda bulunan ve doğal olarak oluşan bir flavonoid glikoziddir [9]. Antioksidan, antialerjik, antibakteriyel, ülser önleyici, antikarsinojenik, anti-diyabetik, antimutajenik, süperoksit radikallerinin güçlü temizleyicisi, immünomodülatör ve nöroprotektif aktiviteler dahil olmak üzere bildirilen birçok farmakolojik özelliğe sahiptir [10, 11]. Bu çalışmada, Rut uygulanmasının, biyokimyasal ve antioksidan içerikleri nedeniyle kolistin kaynaklı rat testis toksisitesinde oksidatif DNA hasarını engelleyebileceği hipotezi öne sürülmüştür. $\mathrm{Bu}$ çalışmanın amacı ayrıca, apoptotik ve enflamatuar (NFผB) protein ekspresyonlarını immünohistokimyasal analizler kullanarak kolistin ile indüklenen apoptoz ve enflamasyon üzerindeki antiapoptotik ve antienflamatuar etkilerini değerlendirmektir.

\section{MATERYAL VE METOT}

\section{1. İlaç ve Kimyasallar}

Çalışmada toksisite sağlamak amacıyla kullanılan kolistin yerel bir ilaç firmasından (Colimycin ${ }^{\circledR} 150$ mg/flakon, Koçak Farma, İstanbul, Türkiye) temin edildi. Rutin ve diğer kimyasallar ise Sigma-Aldrich (St. Louis, MO, ABD) firmasından satın alındı.

\subsection{Deney Hayvanları}

Çalışmada kullanılan deney hayvanları Atatürk Üniversitesi Deneysel Araştırma ve Uygulama Merkezi'nden temin edildi. Deneyde ağırlıkları 220-250 gr arasinda olan 35 adet erkek Sprague Dawley cinsi rat kullanıldı (Etik Kurul Karar No: 2019-4/56). Ratlar $25 \pm$ $1^{\circ} \mathrm{C}^{\prime}$ de ve 12 saatlik bir aydınlık/karanlık 1şık döngüsü ile \% $45 \pm 5$ bağıl nemde metal kafeslere yerleştirildi. Deney dönemi boyunca yem ve su ad libitum sağlandı. Çalışmada kullanılacak ratlar ortama adaptasyon sağlamaları amacıyla, 7 gün boyunca herhangi bir işlem yapilmadan bekletildi.

\subsection{Deneysel Uygulamalar}

Adaptasyon döneminden sonra, 35 erkek Sprague Dawley rat 5 gruba ayrıldı; Grup dizaynları aşağıdaki gibidir:

Grup 1, Kontrol grubu: 7 gün boyunca sadece serum fizyolojik $\left(1 \mathrm{ml}\right.$ gün $\left.^{-1}\right)$ verilen grup.

Grup 2, Rutin uygulanan grup (Rut): Her bir rata 7 gün Rut (100 mg kg gün ${ }^{-1}$ ) verildi [12].

Grup 3, Kolistin uygulanan grup: Her bir rata 7 gün kolistin (15 mg kg gün ${ }^{-1}$ ) periton içi uygulama ile verildi [13].

Grup 4, (Kolistin + Rut 50): Her bir rata, 7 gün boyunca kolistin $\left(15 \mathrm{mg} \mathrm{kg}\right.$ gün $\left.^{-1}\right)$ uygulamasından 1 saat önce Rut (50 mg kg gün ${ }^{-1}$ ) verildi.

Grup 5, (Kolistin + Rut100): Her bir rata, 7 gün boyunca kolistin $\left(15 \mathrm{mg} \mathrm{kg}\right.$ gün $\left.^{-1}\right)$ uygulamasından 1 saat önce Rut (100 mg kg gün ${ }^{-1}$ ) verildi.

Deneyin sonunda, ratlar hafif sevofloran (Sevorane likit $100 \%$, Abbott, İstanbul, Türkiye) ile anesteziye alınarak ötenazi edildi ve testis dokularından biri biyokimyasal analiz için $-80^{\circ} \mathrm{C}^{\prime}$ de saklandı, diğer testis dokusu ise histopatolojik ve immünohistokimyasal analizler için \% 10'luk tamponlu formalin içinde tespit edildi.

\subsection{Doku Homojenatının Hazırlanması}

Her bir hayvanın testisi, yağ ve bağ dokularından arındırıldıktan sonra soğuk izotonik tuzlu su içinde yıkandı ve 1:10 doku ve \% 1.15 tamponlu potasyum klorid içinde homojenize edildi. Doku homojenatları, $4^{\circ}$ C'de 15 dakika 10000 rpm'de santrifüjlendi. Süpernatant topland 1 ve biyokimyasal parametrelerinin değerlendirilmesi için - $80^{\circ} \mathrm{C}$ de sakland1.

\subsection{Biyokimyasal Analizler}

Lipid peroksidasyon içeriği, ratların testis dokusundaki MDA düzeylerinin Placer ve ark [14]. kullandıkları yönteme göre ölçülmesi ile belirlendi. Testis dokularındaki GSH seviyesi ise Sedlak ve Lindsay'ın [15] yöntemi kullanılarak ölçüldü. 


\subsection{Histopatolojik İnceleme}

Her bir ratın testis dokusu trimlendi ve \%10'luk tamponlu formalin solüsyonunda 48 saat süreyle tespit edildi. Testis örnekleri daha sonra dereceli alkol serisiyle dehidre edildi ve parafine gömülmeden önce iki ksilen değişikliği ile şeffaflandırma işlemine tabi tutuldu. Mikrotom aracılığıla (Leica, RM2255) her biri $4 \mu \mathrm{m}$ kalınlığında seri kesitler alındı ve standart yönteme göre hematoksilen ve eozin ile boyand1. Histopatolojik değerlendirme, kontrol grubuna göre uygulama gruplardaki patolojik değişiklikler açısından 1 şı mikroskobu altında yapıld1.

\section{7. İmmunhistokimyasal Analiz}

$4 \mu \mathrm{m}$ kalınlığında polilizinli lam üzerine alınan kesitlerin ksilen içinde parafini uzaklaştırıldıktan sonra dehidrasyon ve hidrasyon işlemleri gerçekleştirildi. Antijenlerin açığa çıkarılması amacıyla, kesitler $10 \mathrm{mM}$ sitrat tamponunda 15 dakika mikrodalgada kaynatıld. Kesitler, endojen peroksidaz aktivitesini engellemek amacıyla 10 dakika süreyle $\% 3$ hidrojen peroksit ile muamele edildi ve sonra PBS ile yıkand1. Kesitler, spesifik olmayan boyamayı azaltmak için protein blok solüsyonu (Ultra V Block, Thermo Fisher Scientific) ile 10 dakika inkübe edildi. Daha sonra 8-OHdG (Kat no: sc-66036, dilüsyon:1/100, Santa Cruz Biotechnology), NF-кB (Kat no: sc-8414, dilüsyon:1/100, Santa Cruz Biotechnology) ve kaspaz 3 (Kat no: sc-56053, dilüsyon:1/100, Santa Cruz Biotechnology) proteinlerine karşı primer monoklonal antikorlar ile oda sıcaklığında nem kabininde 1 saat süreyle inkübe edildi. Kesitler biyotinlenmiş sekonder antikor (Ultra Vision Large Volume Detection System; TP-125-HL; Lab Vision) kullanılarak 10 dakika süreyle inkübe edildi. Antikorun tespiti, kromojen olarak diaminobenzidine (DAB) kullanılarak gerçekleştirildi. Kesitler, Mayer'in hematoksileniyle zit boyandı ve ardindan entellan ile kapatıldı. İmmünboyamanın yoğunluğu şu şekilde derecelendirildi: boyama yok $(0)$, hafif $(1+)$, orta $(2+)$, yoğun $(3+)$. Spermatogenezis ve Leydig hücrelerinin immünboyanmasının yoğunluğu, semi-kantitatif değerlendirme için primer kriterdi.

\section{8. İstatistiksel Analiz}

İstatistiksel hesaplamalar SPSS 20.0 (SPSS, Chicago, IL, USA) kullanılarak yapıldı. Tüm değerler ortalama \pm standart hata olarak ifade edildi. Değerler arasındaki istatistiksel analiz, tek yönlü varyans analizi (ANOVA) ve ardından Tukey post-hoc testi kullanılarak yapıldı. Anlamlılık seviyesi $\mathrm{p}<0.05$ olarak belirlendi.

\section{BULGULAR}

\subsection{Rutinin Kolistin Uygulaması Sonrası Rat Testis Dokularındaki Oksidan/Antioksidan Durumuna Etkisi}

MDA düzeyleri, testis dokularındaki oksidatif hasarı değerlendirmek için kullanıldı. MDA düzeyindeki değişiklikler Şekil 1'de gösterildi. Periton içi kolistin uygulamasından sonra, MDA düzeyleri kontrol grubuna kıyasla önemli ölçüde arttı $(\mathrm{p}<0.05)$. Bununla birlikte, Kolistin + Rut 50 ve Kolistin + Rut 100 dozlarının uygulanmasının, MDA düzeylerini azalttığı tespit edildi $(\mathrm{p}<0.05)$. Kolistin uygulanan ratların testis dokularındaki GSH düzeylerinin önemli derecede azaldı $\breve{g}_{1}$ belirlendi $(p<0.05)$. Ayrica kolistin ile kombine olarak uygulanan Rut 50 veya Rut 100 dozlarının, GSH düzeylerinde önemli bir artışı sağladığı saptand $1 \quad(p<0.05)$. Bu sonuçlar, kolistinin neden olduğu testis hasarının rut ile birlikte uygulanmasıyla azaldığını göstermektedir.

\subsection{Rutinin Kolistin Kaynaklı Histopatolojik Değişikliklere Etkisi}

Kontrol ve Rut uygulanan gruplar normal testis histolojisine sahipti. Seminifer tübüller spermatid hücreleri ile dolu olup ve germinal membran üzerindeki germinal epitel hücreleri düzgün bir şekilde yerleşikti. Leydig hücreleri ve kılcal damar duvarlarının normal olduğu gözlendi (Şekil 2a, Şekil 2b). Buna karşıllık, kolistin uygulanan grubun testis dokuları, spermatogonium çevresinde ödem ve vakuol oluşumu, bazal membranda incelme, interstisyel alanda kılcal damarlarda şiddetli konjesyon ile birlikte spermatojenik hücrelerde ciddi dejeneratif değişiklikler ve nekroz olmak üzere histopatolojik değişiklikler gösterdi (Şekil 2c). Kolistin ile birlikte Rut uygulanması bu histopatolojik değişiklikleri doza bağımlı bir şekilde hafifletmiştir. Kolistin + Rut 50 uygulanması ratlara ait testis dokularındaki dejeneratif değişiklikler ve spermatojenik hücrelerde nekrozu azalttı (Şekil 2d). Kolistin + Rut 100 uygulanması ile testis dokularında hafif dejeneratif değişiklikler ve tam bir spermatogenezis ile normal seminifer tübüller gözlendi (Şekil 2e).

\subsection{Rutinin Testis Dokularındaki 8-OHdG, NF-кB ve Kaspaz-3 İmmunpozitifliği Üzerine Etkileri}

Kontrol grubu ve sadece Rut uygulanan ratların testis dokularında 8-OHdG ekspresyonunun immunhistokimyasal incelemesinde seminifer tübül ve interstisyel doku yapılarında herhangi bir pozitifliğe rastlanmadı (Şekil 3a, Şekil 3b). Kolistin uygulanan grupta spermatogonia ve primer spermatositlerde yoğun immunpozitif hücrelere rastlandı (Şekil 3c). Kolistin uygulanan grup, kontrol ve Rut uygulanan gruplara göre 8-OHdG immunpozitifliğinde anlamlı bir artış gösterdi (Tablo1; p <0.05). Kolistin ile Rut 50 uygulanan grupta benzer hücrelerde immunpozitifliğe rastlanmış olup, kolistin grubuna göre anlamlı bir fark gözlendi (Şekil 3d, Tablo 1; p <0.05). Kolistin + Rut 50 uygulanan grup ile Kolistin + Rut 100 uygulanan grup arasında 8-OHdG immunpozitifliği açısıdan anlamlı bir farklılık gözlenmedi.

Kontrol ve sadece Rut uygulanan grupların testis dokularında NF- $\mathrm{B}$ immunpozitifliği görülmezken (Şekil 4a, Şekil 4b), kolistin uygulanan grupta, her iki gruba kıyasla yoğun immunpozitiflik mevcuttu (Şekil 4c, Tablo1; $\mathrm{p}<0.05$ ). Kolistin ile birlikte Rut 50 uygulanan grupta kolistin grubuna kıyasla immunpozitiflikte önemli bir azalma gözlendi (Şekil 4d). Kolistin + Rut 50 
grubunda NF- $\mathrm{B}$ immunpozitiflikleri spermatogonialarda ve leydig hücrelerinde (Şekil 4d), Kolistin + Rut 100 grubunda (Şekil 4e) ise sadece leydig hücrelerinde pozitifliğe rastlanmakla birlikte NF-кB pozitifliği açısından önemli bir azalmada saptandı (Tablo $1 ; \mathrm{p}<0.05)$.

Şekil 5'de gösterildiği gibi, kolistin grubu, kontrol (Şekil 5a) ve Rut uygulanan gruplara (Şekil 5b) göre kaspaz-3 immunpozitifliğinde anlamlı bir artış gösterdi (Tablo 1; $\mathrm{p}<0.05$ ). Kolistin uygulanan grup (Şekil 5c) ile Kolistin + Rut 50 uygulanan grup (Şekil 5d) arasında anlamlı farklılık saptanmadı (Tablo 1; p >0.05). Öte yandan, daha yüksek dozda Rut uygulaması (Rut 100), kaspaz-3 immunpozitifliğinde kolistin ve düşük doz uygulanan gruplara kıyasla anlamlı bir azalma gösterdi (Şekil 5e, Tablo 1; p <0.05). a

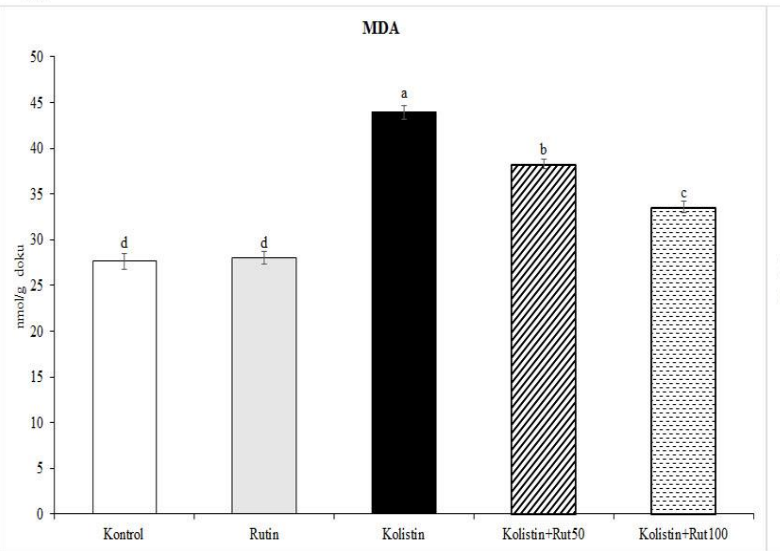

b

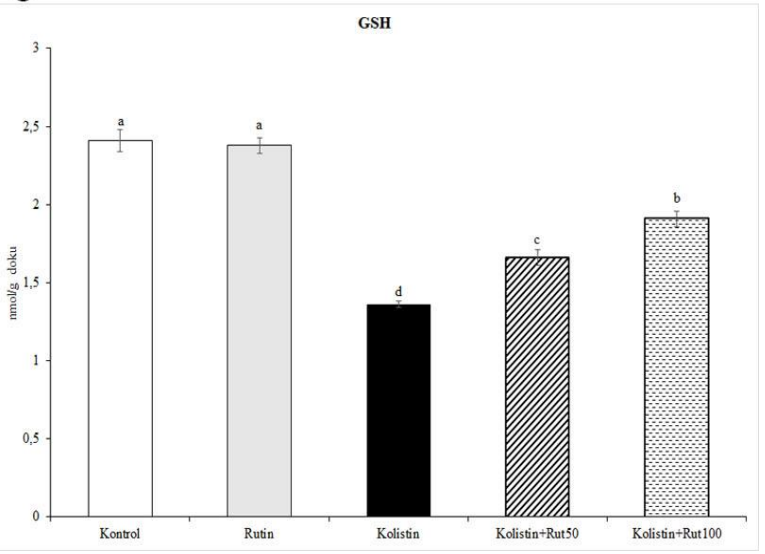

Şekil 1. a) Ratlarda kolistin kaynaklı testis hasarında rutinin MDA düzeyine etkisi. (b) Rutinin ratlarda kolistin kaynaklı testis hasarında GSH seviyesi üzerindeki etkisi. Değerler ortalama \pm SEM olarak verildi. Farklı harfler $(\mathrm{a}-\mathrm{d})$ gruplar arasında istatistiksel farkı göstermektedir $(\mathrm{p}<0.05)$.

Tablo 1. Kolistin ile indüklenen testis hasarında $8-\mathrm{OHdG}, \mathrm{NF}-\kappa \mathrm{B}$ ve kaspaz 3 immunpozitiflikleri üzerine rutinin etkileri

\begin{tabular}{|l|l|l|l|}
\hline Gruplar & $\mathbf{8 - O H d G}$ & NF-кB & Kaspaz 3 \\
\hline Kontrol & $0,14 \pm 0,14^{\mathrm{a}}$ & $0,28 \pm 0,18^{\mathrm{a}}$ & $0,14 \pm 0,14^{\mathrm{a}}$ \\
\hline Rutin & $0,14 \pm 0,14^{\mathrm{a}}$ & $0,14 \pm 0,14^{\mathrm{a}}$ & $0,28 \pm 0,18^{\mathrm{a}}$ \\
\hline Kolistin & $2,85 \pm 0,14^{\mathrm{b}}$ & $2,85 \pm 0,14^{\mathrm{b}}$ & $2,85 \pm 0,14^{\mathrm{b}}$ \\
\hline Kolistin + Rut 50 & $1,28 \pm 0,18^{\mathrm{c}}$ & $1,85 \pm 0,14^{\mathrm{c}}$ & $2,71 \pm 0,18^{\mathrm{b}}$ \\
\hline Kolistin + Rut 100 & $1,14 \pm 0,26^{\mathrm{c}}$ & $0,85 \pm 0,14^{\mathrm{a}}$ & $1,42 \pm 0,20^{\mathrm{c}}$ \\
\hline
\end{tabular}

Değerler ortalama \pm standart hata olarak verilmiştir. Her bir sütundaki farklı harfler gruplar arası farklılığ 1 göstermektedir. ${ }^{\text {a,b,c,d }} \mathrm{p}<0,05$

\section{TARTIŞMA}

Gram-negatif bakteriler, hızla yayılma eğilimleri ve bu patojenler nedeniyle enfeksiyonları etkili bir şekilde tedavi etmek için mevcut azalan terapötik maddeler nedeniyle ABD'deki ve dünya çapındaki hastanelerde bir krize dönüşmüştür. Kolistin, bu ölümcül "süperböceklere" karşı etkili olan az sayıdaki antibiyotik arasında yer almaktadır. Ne yazık ki, doz sınırlayıcı nefrotoksisite ve nörotoksisite, etkili polimiksin tedavisi için engel olmaya devam etmektedir [16]. Bu yan etkilerin iyileştirilmesi, kolistinin terapötik çekiciliğini artıracak ve daha yüksek dozlarda kolistinin uygulanmasına izin verecektir [17]. Oksidatif stres, in vivo veya in vitro olarak ROS ve antioksidan savunma sistemindeki bir dengesizliğin neden olduğu oksidatif hasar sürecini ifade eder [18]. Yapılan çalışmalarda kolistinle oluşturulan toksisitelerde artan ROS üretiminin önemli bir mekanizma olduğu bildirilmiştir [2, 19, 20].
Aşırı ROS seviyeleri DNA, lipidler ve proteinlere zarar verir ve sonunda apoptoza yol açar [21]. MDA, lipid peroksitin parçalanmasıyla oluşan bir grup aldehittir. MDA düzeyinin belirlenmesi genellikle lipid peroksidasyonunun derecesini yansitır [22]. Enzimatik olmayan sistemlerin önemli bir üyesi olan GSH ise hücrelerdeki redoks ortamının korunmasında ve hücreleri oksidatif hasardan korumada yeri doldurulamaz bir rol oynar [23]. Önceki çalışmalarla uyumlu şekilde $[2,7,24,25]$, bulgularımız kolistin uygulaması ile GSH düzeylerinin önemli bir düzeyde azaldığını ve MDA düzeyini artırdığını göstermekte ve testis dokularında bu şekilde oksidatif strese neden olduğunu ortaya koymaktadır. Ayrıca kolistin ile birlikte Rut uygulamasının GSH düzeylerini artırması ve MDA düzeyini azaltması Rut'un antioksidan özelliğini kullanarak oksidatif stresi azaltabileceğini göstermiştir. 


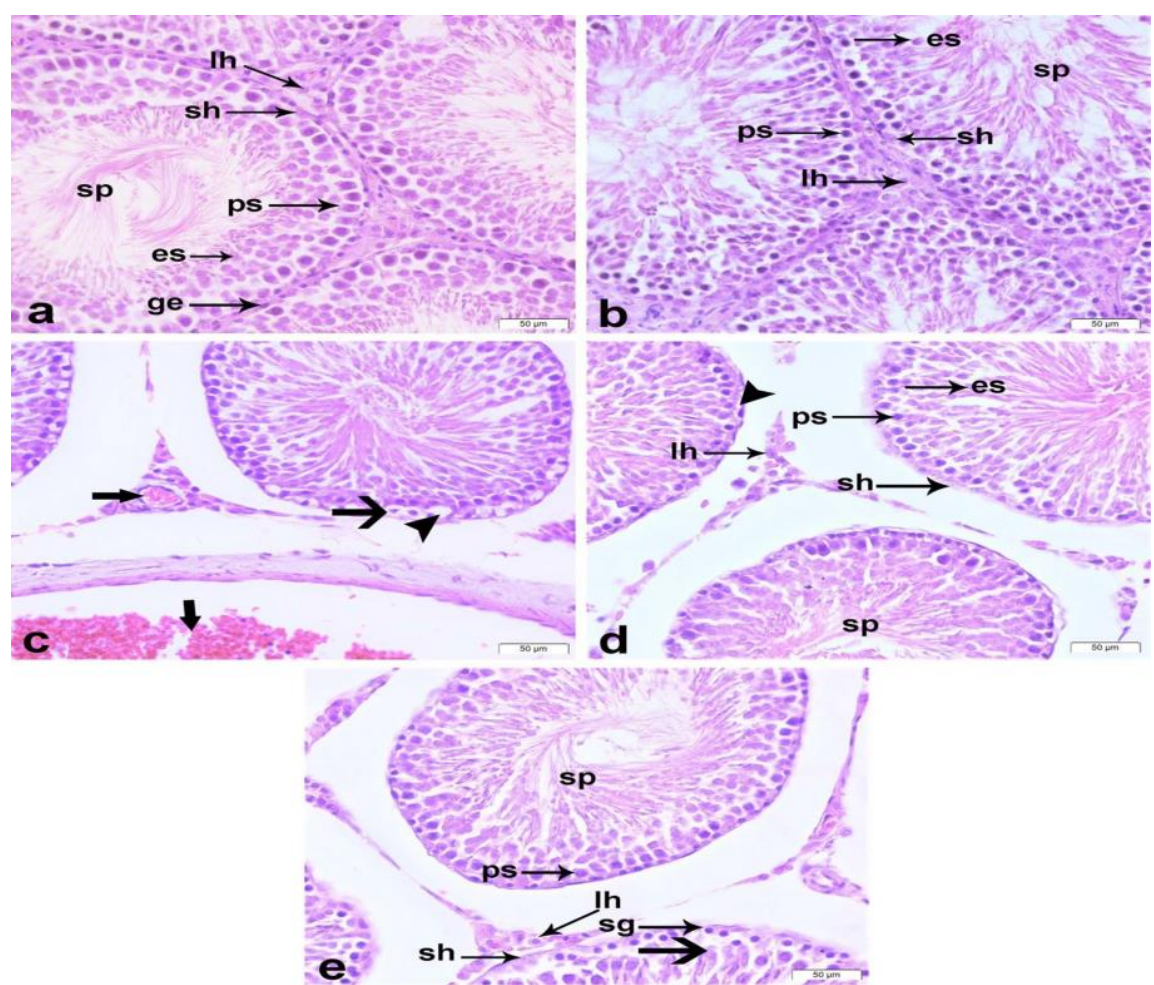

Şekil 2. Kontrol (a), Rutin (b), Kolitin (c), Kolistin + Rut 50 (d), Kolistin + Rut 100 (e) gruplarına ait testis dokularının H\&E (× 40) ile boyanmış histopatolojik fotomikrografları. Kontrol ve rutin gruplarında normal testis histolojik yapısı gözlendi (sh:Sertoli hücresi, ps: primer spermatosit, ge: germinal epitel, es: erken spermatid, sp: spermatid, lh: leydig hücresi); kolistin uygulanan grupta ise germinal epitelde bozulma, vakuol oluşumu (okbaşı), piknotik çekirdek (ince ok) ve damarlarda konjesyon (kalın ok) gözlendi. Kolistin + Rut 50 ve Kolistin + Rut 100 uygulanan gruplarda azalan germinal epitel hücrebir kısmı hasarı (ok ve okbaşı) ve normale yakın spermatogenezis (sh: Sertoli hücresi, ps: primer spermatosit, ge: germinal epitel, sg: spermatogonyumlar, es: erken spermatid, sp: spermatid, lh: leydig hücresi) gözlendi.

MDA, lipid peroksitin parçalanmasılyla oluşan bir grup aldehittir. MDA düzeyinin belirlenmesi genellikle lipid peroksidasyonunun derecesini yansitır [22]. Enzimatik olmayan sistemlerin önemli bir üyesi olan GSH ise hücrelerdeki redoks ortamının korunmasında ve hücreleri oksidatif hasardan korumada yeri doldurulamaz bir rol oynar [23]. Önceki çalışmalarla uyumlu şekilde $[2,7,24,25]$, bulgularımız kolistin uygulaması ile GSH düzeylerinin önemli bir düzeyde azaldığını ve MDA düzeyini artırdığını göstermekte ve testis dokularında bu şekilde oksidatif strese neden olduğunu ortaya koymaktadır. Ayrıca kolistin ile birlikte Rut uygulamasının GSH düzeylerini artırması ve MDA düzeyini azaltması Rut'un antioksidan özelliğini kullanarak oksidatif stresi azaltabileceğini göstermiştir.

Yapılan çalışmalarda, ROS'un nükleotid modifikasyonlarına, DNA zinciri kırılmalarına ve kromatinin çapraz bağlanmasına neden olarak sperm çekirdeğindeki DNA bütünlüğüne saldırdığı öne sürülmüştür [26, 27]. Spermatozoalar, kendi DNA'larına oksidatif serbest radikal saldırılarına karşı sınırlı savunma mekanizmalarına sahip olduklarından, oksidatif DNA hasarı sirasinda 8-OHdG üretilir [28]. 8-OHdG, oksidatif DNA hasarı için en yaygın olarak incelenen biyobelirteçtir [29]. Çeşitli oksidatif DNA eklentileri arasından 8-OHdG, yüksek özgüllüŭgü, güçlü mutajenitesi ve DNA'daki nispi bolluğu nedeniyle oksidatif DNA hasarının bir temsilcisi olarak seçilmiştir [28]. Çalışmamızda kolistin uygulamasına bağlı MDA düzeylerinin arttığı ve lipit peroksidasyonunun oluştuğu belirlenmiştir. Lipid peroksidasyon ürünleri DNA onarım kapasitesini azaltabilir. Bazı araştırmacılar, oksidatif DNA hasarı belirteci olan 8-OHdG ile lipid peroksidasyonu arasında güçlü bir ilişki olduğu sonucuna varmıştır $[30,31]$.

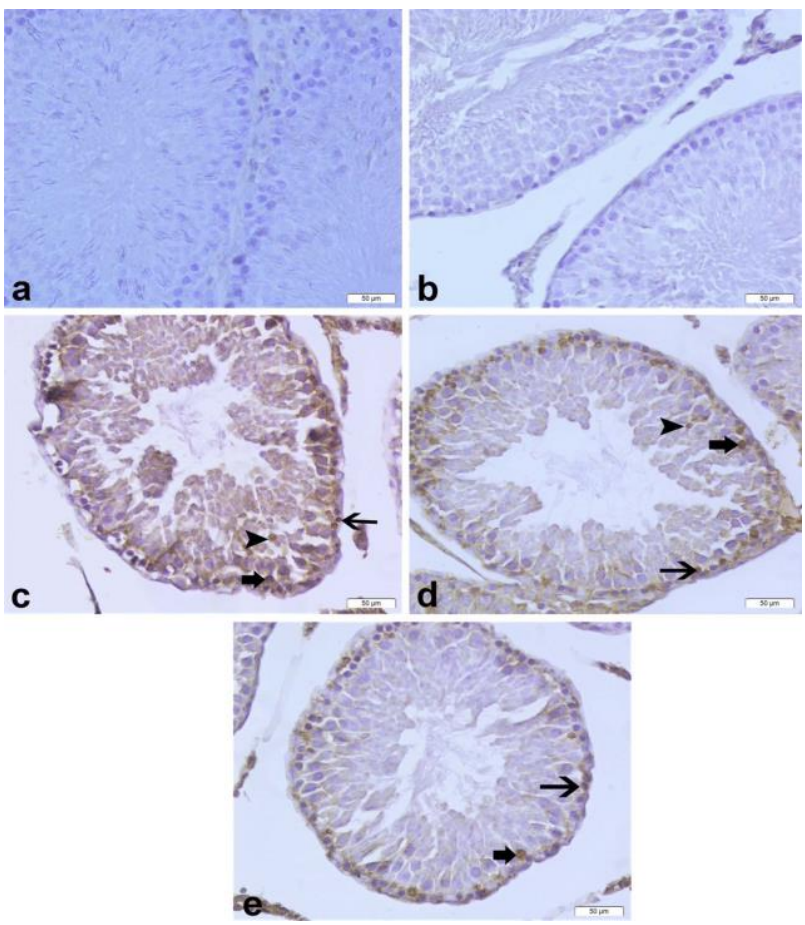

Şekil 3. 8-OHdG'nin rat testis dokularında immünohistokimyasal ekspresyonu, IHC (x40). (a) Kontrol grubu ve (b) rutin uygulanan grup 8-OHdG için negatif immunboyama gösterdi. (c) Kolistin grubu, testis dokusunda spermatogonium (ince ok), primer spermatosit (kalın ok) ve erken spermatidlerde (okbaşı) yoğun 8-OHdG ekspresyonu gösterdi. (d) Kolistin + Rut 50 ve (e) Kolistin + Rut 100 gruplarının testis kesitleri, spermatogonium (ince ok), primer spermatosit (kalın ok) ve erken spermatidlerde (okbaşı) hafif 8-OHdG ekspresyonu gösterdi 
$\mathrm{Bu}$ bilgiler 1şı̆̆ında, sunulan çalışmada testis dokularındaki 8-OHdG seviyeleri ile MDA düzeylerinin kolistin uygulaması ile artması ve Rut antioksidanının uygulanmasına bağlı azalmaları aralarındaki ilişkiyi göstermiş, DNA hasarı üzerinde lipid peroksidasyonunun etkili olduğunu ortaya koymuştur.

NF- $\kappa \mathrm{B}$, oksidatif stres sirasında artan ve stres tepkileri, apoptoz ve bağışıklığın kritik düzenleyicisi olarak bilinen bir transkripsiyon faktörüdür [32]. Oksidatif stres ile aktivasyon üzerine, NF-кB'nin yukarı regülasyonunu tetiklenerek, çok sayıda enflamatuar sitokinin salgılanması ve bir enflamatuar sinyal yolağı başlayabilir [33]. Ayrica, enflamasyonun, anti-inflamatuar ve proinflamatuar sitokinler arasındaki bir dengesizlikten kaynaklandığ1 ve $\mathrm{NF}-\kappa \mathrm{B}$ gibi çeşitli transkripsiyon faktörlerinin enflamasyonu indüklediği bildirilmiştir [34]. NF- $\kappa \mathrm{B}$ aktivasyonu ile indüklenen bu enflamasyon, çeşitli antiinflamatuar ajanlar ve antioksidan inhibitörler tarafindan inhibe edilir [35]. Calıșmamızda Rut'un kolistin kaynaklı testis hasarında indüklenen NF- $\kappa \mathrm{B}$ aktivasyonunu hafiflettiğini gözlemledik (Şekil 4). Bu durum Rut tarafından hücre içi oksidatif stresin

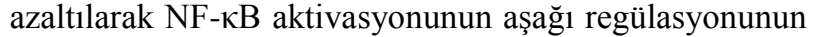
sağlandığ1 ve bu şekilde antiinflamatuar bir özellik gösterdiği ile açıklanabilir.

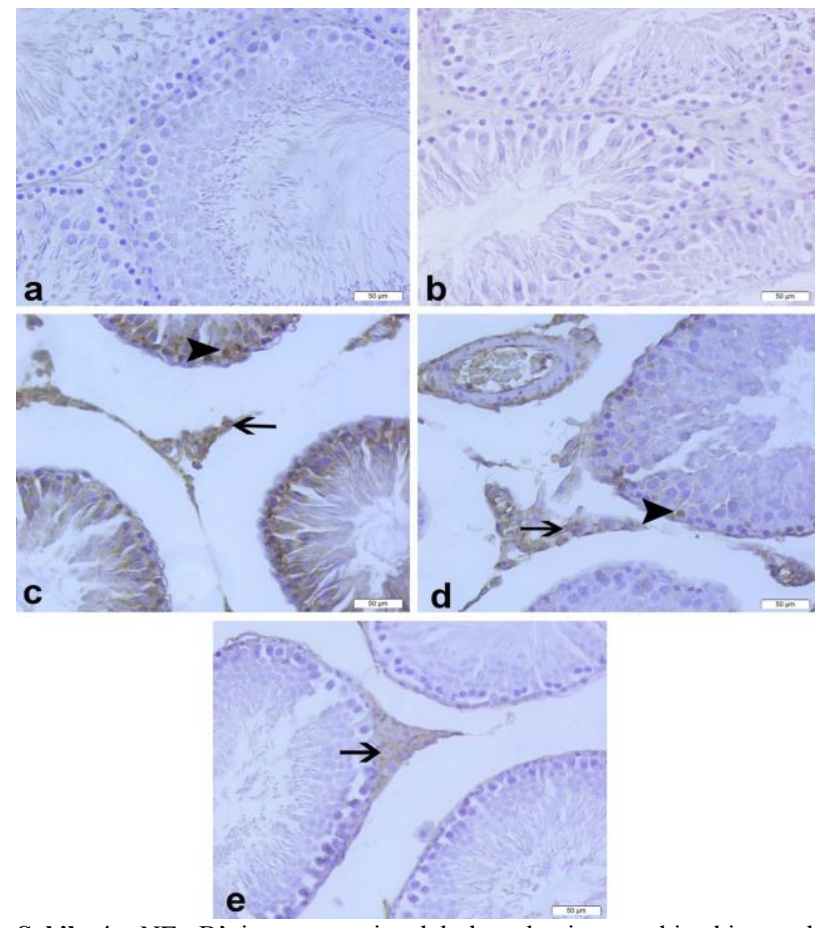

Şekil 4. NF- $\kappa B$ 'nin rat testis dokularında immünohistokimyasal ekspresyonu, IHC (x40). (a) Kontrol grubu ve (b) rutin uygulanan NF$\kappa \mathrm{B}$ için negatif immunboyama gösterdi. (c) Kolistin grubu, testis dokusunda spermatogonium (ok bası) ve leydig hücrelerinde (ince ok) yoğun NF- $\kappa$ B ekspresyonu gösterdi. (d) Kolistin + Rut 50 grubu spermatogonium (ok başı) ve leydig hücrelerinde (ince ok) orta yoğunlukta NF- $\kappa \mathrm{B}$ ekspresyonu gösterdi. (e) Kolistin + Rut 100 gruplarının testis kesitleri, sadece leydig hücrelerinde (ince ok) hafif $\mathrm{NF}-\kappa \mathrm{B}$ ekspresyonu gösterdi.

Apoptoz süreci, hücre dışı (ekstrinsik indükleyiciler) veya hücre içi (intrinsik indükleyiciler) kaynaklı olabilen çok çeşitli hücre sinyalleri tarafindan kontrol edilir. Hücre dışı sinyaller, ya plazma membranını geçmesi ya da bir tepkiyi etkilemek için transdüksiyonu yapması gereken toksinler, hormonlar, büyüme faktörleri, nitrik oksit ya da sitokinleri içerebilir [36, 37]. Bu sinyaller, apoptozu pozitif (yani tetikleyebilir) veya negatif (yani baskılayabilir, inhibe edebilir veya azaltabilir) yönden etkileyebilir. Glukokortikoidler, 1s1, radyasyon, besin yoksunluğu, viral enfeksiyon, toksik ilaçlar ve hipoksinin neden olduğu hücre hasarında hücre içi apoptotik sinyallerin salınması tetiklenebilir [38]. Kolistindeki 5 pozitif yüklü amino grubunun yapısı, Na ,$+ \mathrm{K}+$ ve $\mathrm{Ca} 2+$ konsantrasyonunu etkileyerek zar geçirgenliğini değiştirerek bakterileri öldürmenin ve memeli hücrelerinde toksisiteye neden olan ana yap1 olarak kabul edilir [39]. Kolistinin, yağ asidi bileşenleri nedeniyle lipit membranını değiştirme veya bozma yeteneği, yüksek düzeyde toksisite hassasiyetini açıklamaya yardımcı olabilir [40]. Kaspaz 3 hem hücre dışı hem de hücre içi apoptoz da görev alan önemli bir proteindir. Daha önce yapılan çalışmalarda kolistinin kaspaz 3 ekspresyonunu arttırarak apoptozu indüklediği gösterilmiştir [41-44]. Yapılan bu çalışmada kaspaz 3 immunpozitifliğinin kontrol ve sadece Rut uygulanan grupta değişmediği, Kolistin ve Kolistin + Rut 50 uygulanan grupta önemli derecede arttığı, kolisitnle birlikte Rut 100 uygulaması sonrası ise bu immunpozitifliğin azaldığı gözlemlenmiştir. Rut uygulamasının kaspaz 3 seviyesini azalttığı ve apoptoz aktivitesini düşürdüğü önceki çalışmalarda rapor edilmiştir [42, 45-49]. Dolayısıyla bu çalışmadan elde edilen veriler önceki çalışmalarla uyumlu olarak bulunmuştur.

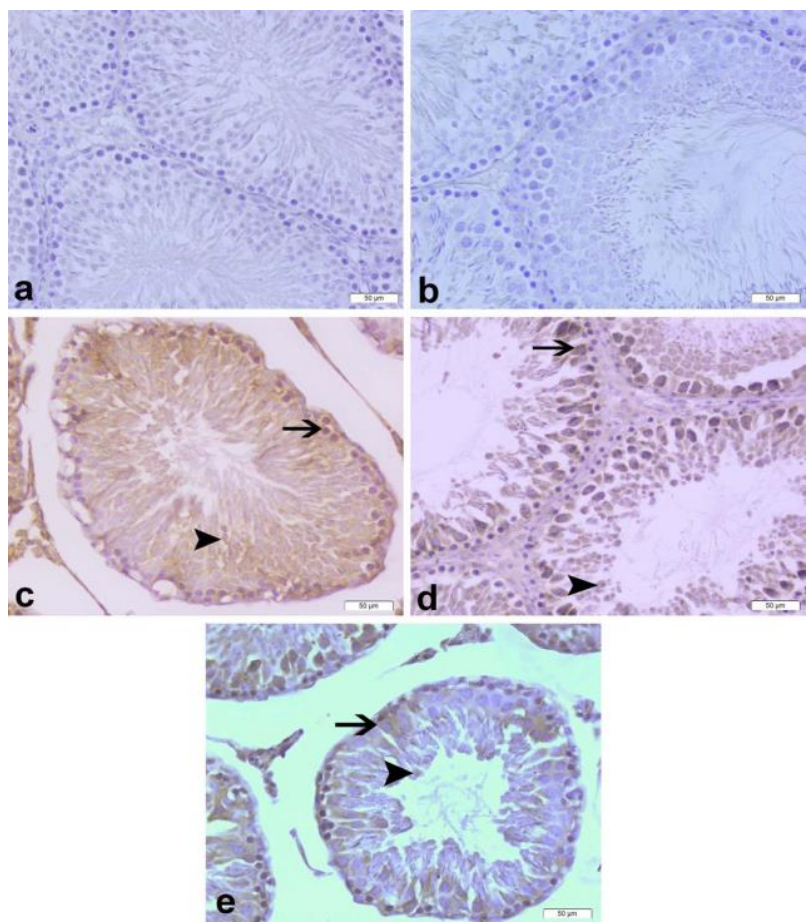

Şekil 5. Kaspaz 3'ün rat testis dokularında immünohistokimyasa ekspresyonu, IHC (x40). (a) Kontrol grubu ve (b) rutin uygulanan kaspaz 3 için negatif immunboyama gösterdi. (c) Kolistin grubu ve (d) Kolistin + Rut 50 grubunun testis dokuları spermatogonium (ok) ve spermatidlerde (ok başı) yoğun kaspaz 3 ekspresyonu gösterdi. (e) Kolistin + Rut 100 gruplarının testis kesitleri, primer spermatosit (ince ok) ve spermatidlerde (okbaşı) hafif düzeyde kaspaz 3 ekspresyonu gösterdi. 
Çalışmada elde edilen veriler, Rut'un enflamasyon ve apoptozda yer alan NF-kB ve caspase 3 seviyelerini azaltarak testis dokusunda kolistin kaynaklı hasarı zayıflattığını göstermektedir. Rut'un bu anti-inflamatuar ve anti-apoptotik etkilerine lipit peroksidasyonunun azalması ile oksidatif stresin baskılanması aracılık eder. Sonuç olarak bu çalışma, kolistin uygulaması ile birlikte ortaya çıkabilecek muhtemel hasarın azaltılmasında Rut'un da birlikte klinik uygulaması için temel destekleyici veriler sağlamaktadır.

\section{KAYNAKLAR}

[1] Hanedan B, Ozkaraca M, Kirbas A, Kandemir FM, Aktas MS, Kilic K, et al. Investigation of the effects of hesperidin and chrysin on renal injury induced by colistin in rats. Biomed Pharmacother. 2018; 108:1607-16.

[2] Çelik H, Kandemir FM, Caglayan C, Özdemir S, Çomaklı S, Kucukler S, et al. Neuroprotective effect of rutin against colistin-induced oxidative stress, inflammation and apoptosis in rat brain associated with the CREB/BDNF expressions. Mol Biol Rep. 2020; 47(3):2023-34.

[3] Zavascki AP, Goldani LZ, Li J, Nation RL. Polymyxin B for the treatment of multidrugresistant pathogens: a critical review. J Antimicrob Chemother. 2007; 60(6):1206-15.

[4] Heidari R, Behnamrad S, Khodami Z, Ommati MM, Azarpira N, Vazin A. The nephroprotective properties of taurine in colistin-treated mice is mediated through the regulation of mitochondrial function and mitigation of oxidative stress. Biomed Pharmacother. 2019; 109:103-11.

[5] Dai C, Li J, Li J. New insight in colistin induced neurotoxicity with the mitochondrial dysfunction in mice central nervous tissues. Exp Toxicol Pathol. 2013; 65(6):941-8.

[6] Yu Z, Zhu Y, Qin W, Yin J, Qiu J. Oxidative stress induced by polymyxin $\mathrm{E}$ is involved in rapid killing of Paenibacillus polymyxa. Biomed Res Int. 2017; 2017.

[7] Aksu EH, Kandemir FM, Küçükler S, Mahamadu A. Improvement in colistin-induced reproductive damage, apoptosis, and autophagy in testes via reducing oxidative stress by chrysin. J Biochem Mol Toxicol. 2018; 32(11):e22201.

[8] Kandemir FM, Caglayan C, Aksu EH, Yildirim S, Kucukler S, Gur C, et al. Protective effect of rutin on mercuric chloride-induced reproductive damage in male rats. Andrologia. 2020; 52(3):e13524.

[9] Aksu E, Kandemir F, Özkaraca M, Ömür A, Küçükler S, Çomaklı S. Rutin ameliorates cisplatininduced reproductive damage via suppression of oxidative stress and apoptosis in adult male rats. Andrologia. 2017; 49(1):e12593.

[10] Ganeshpurkar A, Saluja AK. The pharmacological potential of rutin. Saudi Pharm J. 2017; 25(2):14964.

[11] Caglayan C, Kandemir FM, Darendelioğlu E, Yildırım S, Kucukler S, Dortbudak MB. Rutin ameliorates mercuric chloride-induced hepatotoxicity in rats via interfering with oxidative stress, inflammation and apoptosis. J Trace Elem Med Biol. 2019; 56:60-8.

[12] Caglayan C, Kandemir FM, Yildirim S, Kucukler $\mathrm{S}$, Eser G. Rutin protects mercuric chloride-induced nephrotoxicity via targeting of aquaporin 1 level, oxidative stress, apoptosis and inflammation in rats. J Trace Elem Med Biol. 2019; 54:69-78.

[13] Ajiboye T. Colistin sulphate induced neurotoxicity: Studies on cholinergic, monoaminergic, purinergic and oxidative stress biomarkers. Biomed Pharmacother. 2018; 103:1701-7.

[14] Placer ZA, Cushman LL, Johnson BC. Estimation of product of lipid peroxidation (malonyl dialdehyde) in biochemical systems. Anal Biochem. 1966; 16(2):359-64.

[15] Sedlak J, Lindsay RH. Estimation of total, proteinbound, and nonprotein sulfhydryl groups in tissue with Ellman's reagent. Anal Biochem. 1968; 25:192-205.

[16] Dai C, Tang S, Wang Y, Velkov T, Xiao X. Baicalein acts as a nephroprotectant that ameliorates colistin-induced nephrotoxicity by activating the antioxidant defence mechanism of the kidneys and down-regulating the inflammatory response. J Antimicrob Chemother. 2017; 72(9):2562-9.

[17] Edrees NE, Galal AA, Monaem ARA, Beheiry RR, Metwally MM. Curcumin alleviates colistininduced nephrotoxicity and neurotoxicity in rats via attenuation of oxidative stress, inflammation and apoptosis. Chem Biol Interact. 2018; 294:56-64.

[18] Birben E, Sahiner UM, Sackesen C, Erzurum S, Kalayci O. Oxidative stress and antioxidant defense. World Allergy Organization Journal. 2012; 5(1):9-19.

[19] Yousef JM, Chen G, Hill PA, Nation RL, Li J. Melatonin attenuates colistin-induced nephrotoxicity in rats. Antimicrob Agents Chemother. 2011; 55(9):4044-9.

[20] Dai C, Zhang D, Gao R, Zhang X, Li J, Li J. In vitro toxicity of colistin on primary chick cortex neurons and its potential mechanism. Environ Toxicol Pharmacol. 2013; 36(2):659-66.

[21] Dai C, Tang S, Deng S, Zhang S, Zhou Y, Velkov $\mathrm{T}$, et al. Lycopene attenuates colistin-induced nephrotoxicity in mice via activation of the Nrf2/HO-1 pathway. Antimicrob Agents Chemother. 2015; 59(1):579-85.

[22] Chi X, Bi S, Xu W, Zhang Y, Liang S, Hu S. Oral administration of tea saponins to relive oxidative stress and immune suppression in chickens. Poult Sci. 2017; 96(9):3058-67.

[23] Zhang Y, Chi X, Wang Z, Bi S, Wang Y, Shi F, et al. Protective effects of Panax notoginseng saponins on PME-Induced nephrotoxicity in mice. Biomed Pharmacother. 2019; 116:108970.

[24] Jiang G-Z, Li J-C. Protective effects of ginsenoside Rg1 against colistin sulfate-induced neurotoxicity in PC12 cells. Cell Mol Neurobiol. 2014; 34(2):167-72.

[25] Wang J, Ishfaq M, Xu L, Xia C, Chen C, Li J. METTL3/m6A/miRNA-873-5p Attenuated Oxidative Stress and Apoptosis in Colistin-Induced 
Kidney Injury by Modulating Keap1/Nrf2 Pathway. Front Pharmacol. 2019; 10:517.

[26] Hosen MB, Islam MR, Begum F, Kabir Y, Howlader MZH. Oxidative stress induced sperm DNA damage, a possible reason for male infertility. Iran J Reprod Med. 2015; 13(9):525.

[27] Said TM, Agarwal A, Sharma RK, Thomas Jr AJ, Sikka SC. Impact of sperm morphology on DNA damage caused by oxidative stress induced by $\beta$ nicotinamide adenine dinucleotide phosphate. Fertil Steril. 2005; 83(1):95-103.

[28] Shen H-M, Ong C-N. Detection of oxidative DNA damage in human sperm and its association with sperm function and male infertility. Free Radic Biol Med. 2000; 28(4):529-36.

[29] Özdemir S, Kucukler S, Çomaklı S, Kandemir FM. The protective effect of Morin against ifosfamideinduced acute liver injury in rats associated with the inhibition of DNA damage and apoptosis. Drug Chem Toxicol. 2020:1-10.

[30] Wong YT, Ruan R, Tay FEH. Relationship between levels of oxidative DNA damage, lipid peroxidation and mitochondrial membrane potential in young and old F344 rats. Free Radic Res. 2006; 40(4):393-402.

[31] Park J-W, Floyd RA. Lipid peroxidation products mediate the formation of 8-hydroxydeoxyguanosine in DNA. Free Radic Biol Med. 1992; 12(4):245-50.

[32] Kucukler S, Darendelioğlu E, Caglayan C, Ayna A, Yildırım S, Kandemir FM. Zingerone attenuates vancomycin-induced hepatotoxicity in rats through regulation of oxidative stress, inflammation and apoptosis. Life Sci. 2020:118382.

[33] Aprioku JS. Pharmacology of free radicals and the impact of reactive oxygen species on the testis. J Reprod Infertil. 2013; 14(4):158.

[34] Kandemir FM, Yıldırım S, Kucukler S, Caglayan C, Darendelioğlu E, Dortbudak MB. Protective effects of morin against acrylamide-induced hepatotoxicity and nephrotoxicity: A multibiomarker approach. Food Chem Toxicol. 2020; 138:111190.

[35] Shishodia S, Majumdar S, Banerjee S, Aggarwal BB. Ursolic acid inhibits nuclear factor- $\kappa B$ activation induced by carcinogenic agents through suppression of $\mathrm{I} \kappa \mathrm{B} \alpha$ kinase and p65 phosphorylation: correlation with down-regulation of cyclooxygenase 2, matrix metalloproteinase 9, and cyclin D1. Cancer Res. 2003; 63(15):4375-83.

[36] Thompson CB. Apoptosis in the pathogenesis and treatment of disease. Science. 1995;267(5203):1456-62.

[37] Rubin LL. Neuronal cell death: when, why and how. Br Med Bull. 1997; 53(3):617-31.

[38] Mattson MP, Chan SL. Calcium orchestrates apoptosis. Nat Cell Biol. 2003; 5(12):1041-3.

[39] Falagas ME, Kasiakou SK. Toxicity of polymyxins: a systematic review of the evidence from old and recent studies. Crit Care. 2006; 10(1):R27.

[40] Dai C, Li J, Lin W, Li G, Sun M, Wang F, et al. Electrophysiology and ultrastructural changes in mouse sciatic nerve associated with colistin sulfate exposure. Toxicol Mech Methods. 2012; 22(8):5926.

[41] Dai C, Xiao X, Zhang Y, Xiang B, Hoyer D, Shen $\mathrm{J}$, et al. Curcumin Attenuates Colistin-Induced Peripheral Neurotoxicity in Mice. ACS Infect Dis. 2020; 6(4):715-24.

[42] Çelik H, Kandemir FM, Caglayan C, Özdemir S, Çomaklı S, Kucukler S, et al. Neuroprotective effect of rutin against colistin-induced oxidative stress, inflammation and apoptosis in rat brain associated with the CREB/BDNF expressions. Mol Biol Rep. 2020; 47(3):2023-34.

[43] Dai C, Xiong J, Wang Y, Shen J, Velkov T, Xiao $\mathrm{X}$. Nerve Growth Factor Confers Neuroprotection against Colistin-Induced Peripheral Neurotoxicity. ACS Infect Dis. 2020; 6(6):1451-9.

[44] Wang J, Ishfaq M, Fan Q, Chen C, Li J. 7 Hydroxycoumarin Attenuates Colistin-Induced Kidney Injury in Mice Through the Decreased Level of Histone Deacetylase 1 and the Activation of Nrf2 Signaling Pathway. Front Pharmacol. 2020; 11:1146.

[45] Yaşar H, Ersoy A, Cimen FK, Mammadov R, Kurt $\mathrm{N}$, Arslan YK. Peripheral neurotoxic effects of cisplatin on rats and treatment with rutin. Adv Clin Exp Med. 2019; 28(11):1537-43.

[46] Abdelfattah MS, Badr SEA, Lotfy SA, Attia GH, Aref AM, Abdel Moneim AE, et al. Rutin and Selenium Co-administration Reverse 3Nitropropionic Acid-Induced Neurochemical and Molecular Impairments in a Mouse Model of Huntington's Disease. Neurotox Res. 2020; 37(1):77-92.

[47] Caglayan C, Kandemir FM, Darendelioğlu E, Yıldırım S, Kucukler S, Dortbudak MB. Rutin ameliorates mercuric chloride-induced hepatotoxicity in rats via interfering with oxidative stress, inflammation and apoptosis. J Trace Elem Med Biol. 2019; 56:60-8.

[48] Khan F, Pandey P, Upadhyay TK, Jafri A, Jha NK, Mishra R, et al. Anti-Cancerous Effect of Rutin Against HPV-C33A Cervical Cancer Cells via G0/G1 Cell Cycle Arrest and Apoptotic Induction. Endocr Metab Immune Disord Drug Targets. 2020; 20(3):409-18.

[49] Gao H, Yuan X, Wang Z, Gao Q, Yang J. Profiles and neuroprotective effects of Lycium ruthenicum polyphenols against oxidative stress-induced cytotoxicity in PC12 cells. J Food Biochem. 2020; 44(1):e13112. 